\title{
Petrochemistry of upper mantle eclogites from the Grizzly, Leslie, Pigeon and Sable kimberlites in the Slave Province, Canada
}

Fung, A.T.

\section{C.F. Mineral Research Limited, 1677 Powick Road, Kelowna, British Columbia, Canada V1X 4L1}

Xenoliths entrained in kimberlites provide important information on the chemistry and evolution of the upper mantle. Eclogite xenoliths are of particular interest because of a 'multiplicity of origins' (Snyder et al., 1997 and references therein) and their association with diamonds. Petrography and mineral compositions were determined for 44 eclogites from the Grizzly, Leslie, Pigeon and Sable kimberlites in the Slave Province, Canada (Figure 1). The objectives of this study are to characterize the chemical diversity among the xenoliths and constrain their equilibration conditions in the upper mantle.

The eclogites (up to $13 \mathrm{~cm}$ in size) in this study are coarse grained, equigranular and display garnet to clinopyroxene ratios of $75: 25$ to $25: 75$. (jarnets $(0.5-10 \mathrm{~mm})$ are pale to dark orange, rounded to anhedral, fractured and commonly rimmed by kelyphites composed of phlogopite + amphibole or irresolvable materials. Clinopyroxenes $(3-11 \mathrm{~mm})$ are pale green to emerald green, anhedral, interstitial to garnet grains, and typically altered to a white, spongy product. Grizzly sample GE17 contains 35-40 modal\% of clear yellow, subhedral, accessory olivines (5mm). Secondary and metasomatic phases (phlogopite, amphibole, rutile, ilmenite, spinel, pyrite, pyrrhotite, calcite and feldspar) constitute less than 10 modal $\%$ in the xenoliths.

Mineral compositions were determined by a CAMECA SX-50 electron microprobe at C.F. Mineral Research. Garnets in the Grizzly, Leslie and Sable eclogites exhibit a wide spread of major element compositions (Table 1), ranging from $\mathrm{Py}_{69} \mathrm{Alm}_{18} \mathrm{Gross}_{13}$ to $\mathrm{Py}_{18} \mathrm{Alm}_{63} \mathrm{Gross}_{19}$ (Figure 2). Except for sample PGE1, the Pigeon eclogites cluster tightly within the high-Mg, Group A field established by Coleman et al. (1965). Five eclogites (GE1, LE3, LE7, LE9 and PGE1) contain garnets that are surrounded by distinctly pyropic rims. The rims display substantial micron-scale zoning (Figure 3 ) and are enriched in $\mathrm{MgO}$ by more than 5-10 wt\%. Corresponding clinopyroxenes in the eclogite suite show a narrow $\mathrm{Mg}$-Fe-Ca array (average $\mathrm{Wo}_{48} \mathrm{En}_{43} \mathrm{Fs}_{9}$ ) but differ strongly in the jadeite and diopside components $\left(\mathrm{Jd}_{2} \mathrm{Di}_{98}\right.$ to $\mathrm{Jd}_{44} \mathrm{Di}_{56}$; Figure 4) The fine grained, spongy pyroxenes observed in some xenoliths are more diopsidic than unaltered counterparts and possibly resulted from metasomatism (Snyder et al., 1997) or partial melting (Haggerty et al., 1994).

Apatite, garnet, rutile and ilmenite lamellae $(<200 \mu \mathrm{m})$ have been recognized within primary minerals. In some cases, oriented apatite + rutile or rutile + ilmenite coexist in the same host grain. Fluor-apatite crystals $\left(55.5 \mathrm{wt} \% \mathrm{CaO}, 42.9 \mathrm{wt} \% \mathrm{P}_{2} \mathrm{O}_{5}\right)$ in garnet and pyroxene have been confirmed in four eclogites (GE1, GE2, LE2 and LE4). Previous studies have suggested the coupled substitution of $\mathrm{P}$ for $(\mathrm{Na}+\mathrm{Ti})$ in mantle garnets (e.g., Bishop et al., 1978) and interpreted apatites as exsolution products, rather than accidental inclusions (Haggerty et al., 1994). Garnet exsolved from clinopyroxene in Grizzly eclogite GE6 resembles primary garnet in terms of mineral compositions (average $\mathrm{Py}_{33} \mathrm{Alm}_{42} \mathrm{Gross}_{25}$ ).

Accessory olivines in sample GE17 are fosteritic $\left(\mathrm{Fo}_{69.7}\right)$ with an average $\mathrm{NiO}$ content of $0.36 \mathrm{wt} \%$. Secondary phlogopites account for $5-7$ modal $\%$ in some xenoliths and contain $097-4.00 \mathrm{wt} \% \mathrm{TiO}_{2}$ 
Rutile, the most common oxide in these eclogites, has up to $1.63 \mathrm{wt} \% \mathrm{Nb}_{2} \mathrm{O}_{5}$. Interstitial rutile and ilmenite (1.07-8.67 wt\% MgO) exhibit similar chemistry to those occurring as lamellae.

The distribution coefficient $\mathrm{K}_{\mathrm{D}}$ values of $\mathrm{Fe}-\mathrm{Mg}$ in coexisting garnet and clinopyroxene range from 2.73 to 7.52 . At an assumed pressure of $45 \mathrm{~kb}$, equilibration temperatures of the eclogites were calculated using the Ellis and Green (1979) geothermometer. Projecting the temperatures onto a typical cratonic geotherm $\left(40 \mathrm{~mW} / \mathrm{m}^{2}\right)$ yields P-T conditions of $725-1438^{\circ} \mathrm{C}$ at $25-85 \mathrm{~kb}$. On average, Sable eclogites show the highest P-T, followed by Pigeon, Grizzly and Leslie eclogites. The broad range in equilibration P-T implies that eclogites in this study may have originated in different regions in the upper mantle. Of the ten xenoliths which fall within the diamond stability field (Kennedy and Kennedy, 1976), two Sable eclogites, SE4 and SE8, display unusually high P-T of $1269^{\circ} \mathrm{C}$ at $66 \mathrm{~kb}$ and $1438^{\circ} \mathrm{C}$ at $85 \mathrm{~kb}$ respectively. Based on equilibration conditions, eclogites are likely an important contributor to the diamond populations in the Sable kimberlite. This is consistent with diamond inclusion data (I. Chinn, pers. comm., 1998) and the presence of Group I (McCandless and Gurney, 1989) eclogitic garnets in representative heavy mineral concentrates from the Sable kimberlite (J. Carlson, pers. comm., 1998).

\section{Acknowledgments}

BHP Minerals and Dia Met Minerals are gratefully acknowledged for providing xenoliths and permission to publish. The project was supported by C.F. Minerals. D. Bruce (BHP) drafted the kimberlite location map

A. Bauslaugh maintained the microprobes at CFM and assisted in collecting secondary electron images.

\section{References}

Bishop, F.C., Smith, J.V.. and Dawson, J.B., 1978, Na, K, P and Ti in garnet, pyroxene and olivine from peridotite and eclogite xenoliths from African kimberlites: Lithos, 11, p. 155-173.

Coleman. R.G., Lee, D.E., Beatty, L.B., and Erannock, W.W., 1965, Eclogites and eclogites: Their differences and similarities: Geol. Soc. Am. Bull., 76, p. 483-508.

Ellis, D. J., and Green, D. H., 1979, An experimental study of the effect of Ca upon garnet-clinopyroxene Fe-Mg exchange equilibria: Contrib. Mineral. Petrol., 71, p. 13-22.

Haggerty, S. E., Fung, A. T., and Burt, D. M., 1994, Apatite, phosphorus and titanium in eclogitic garnets in the upper mantle: Geophys. Res. Lett., 21, p. 1699-1702.

Kennedy, C.S., and Kennedy, G.C., 1976, The equilibrium boundary between graphite and diamond: J Geophys. Res., 81, p. 2467-2470.

McCandless, T.E., and Gurney, J.J., 1989, Sodium in garnet and potassium in clinopyroxene: criteria for classifying mantle eclogites: Kimb. and Related Rocks, Spec. Publ. - Geol. Soc. Aust., 14, p. 827-832.

Snyder. G.A., Taylor, L.A., Crozaz, G., Halliday, A.N., Beard, B.L., Sobolev, V.N . and Sobolev, N.V., 1997. The origins of Yakutian eclogite xenoliths: J. Petrol., 38, p. 85-113.

Table 1. Representative garnet compositions of the Slave Province eclogites

\begin{tabular}{|c|c|c|c|c|c|c|c|c|c|c|c|c|c|c|c|c|c|c|}
\hline & Grizz & y garnets & & & & & & & & & & & & & & _eslie ga & arnets & \\
\hline & GE1 & GE2 & GE3 & GE4 & GE5 & GE6 & GE7 & GE8 & GE10 & GE11 & GE12 & GE13 & GE15 & GE16 & GE17 & LE1 & LE2 & LE3 \\
\hline $\mathrm{SiO} 2$ & 39.48 & 37.63 & 40.46 & 40.30 & 40.06 & 39.34 & 41.35 & 40.22 & 41.70 & 41.35 & 41.45 & 41.91 & 37.38 & 38.41 & 40.31 & 40.72 & 38.24 & 38.60 \\
\hline TiO2 & 0.18 & 0.07 & 0.16 & 0.18 & 0.21 & 0.13 & 0.39 & 0.20 & 0.16 & 0.31 & 0.36 & 0.27 & 0.07 & 0.07 & 0.19 & 0.05 & 0.11 & 0.31 \\
\hline $\mathrm{Al} 2 \mathrm{O} 3$ & 22.71 & 21.31 & 23.01 & 22.69 & 22.36 & 22.30 & 22.32 & 22.72 & 23.53 & 23.22 & 22.71 & 23.22 & 21.30 & 21.89 & 23.19 & 20.80 & 21.68 & 22.28 \\
\hline $\mathrm{Cr} 2 \mathrm{O} 3$ & 0.05 & 0.03 & 0.10 & 0.06 & 0.09 & 0.04 & 1.47 & 0.34 & 0.58 & 0.33 & 0.75 & 1.09 & 0.02 & 0.06 & 0.12 & 3.00 & 0.09 & 0.06 \\
\hline $\mathrm{FeO}$ & 17.83 & 28.25 & 15.89 & 15.56 & 15.10 & 19.61 & 9.51 & 13.96 & 9.21 & 10.93 & 10.74 & 8.09 & 28.54 & 26.13 & 15.97 & 11.56 & 26.32 & 20.47 \\
\hline $\mathrm{MnO}$ & 0.39 & 1.01 & 0.41 & 0.37 & 0.38 & 0.45 & 0.57 & 0.34 & 0.37 & 037 & 0.37 & 0.46 & 1.02 & 0.76 & 0.37 & 0.61 & 0.63 & 0.46 \\
\hline $\mathrm{CaO}$ & 5.76 & 6.80 & 5.32 & 8.29 & 8.34 & 9.07 & 5.81 & 9.18 & 4.90 & 4.75 & 4.12 & 4.25 & 6.82 & 6.69 & 4.38 & 5.66 & 6.34 & 11.08 \\
\hline $\mathrm{NiO}$ & 0.03 & 0.03 & 0.04 & 0.00 & 0.02 & 0.01 & 0.03 & 0.00 & 0.03 & 0.07 & 0.04 & 0.00 & 0.06 & 0.01 & 0.04 & 0.00 & 000 & 0.01 \\
\hline $\mathrm{Na} 2 \mathrm{O}$ & 0.05 & 0.02 & 0.05 & 0.06 & 0.03 & 0.04 & 0.05 & 0.07 & 0.03 & 0.06 & 006 & 0.06 & 0.01 & 0.01 & 0.03 & 0.02 & 0.01 & 0.10 \\
\hline P2O5 & 0.06 & 0.02 & 0.03 & 0.04 & 0.05 & 0.04 & 0.02 & 0.04 & 0.05 & 0.04 & 0.02 & 0.01 & 0.02 & 0.03 & 0.01 & 0.01 & 0.07 & 0.08 \\
\hline total & 99.66 & 100.03 & 99.82 & 100.47 & 99.32 & 99.75 & 99.77 & 99.99 & 99.94 & 100.33 & 99.94 & 100.41 & 99.84 & 100.15 & 100.09 & 99.74 & 100.42 & $\begin{array}{l}100.26 \\
\text { (cont.) }\end{array}$ \\
\hline
\end{tabular}




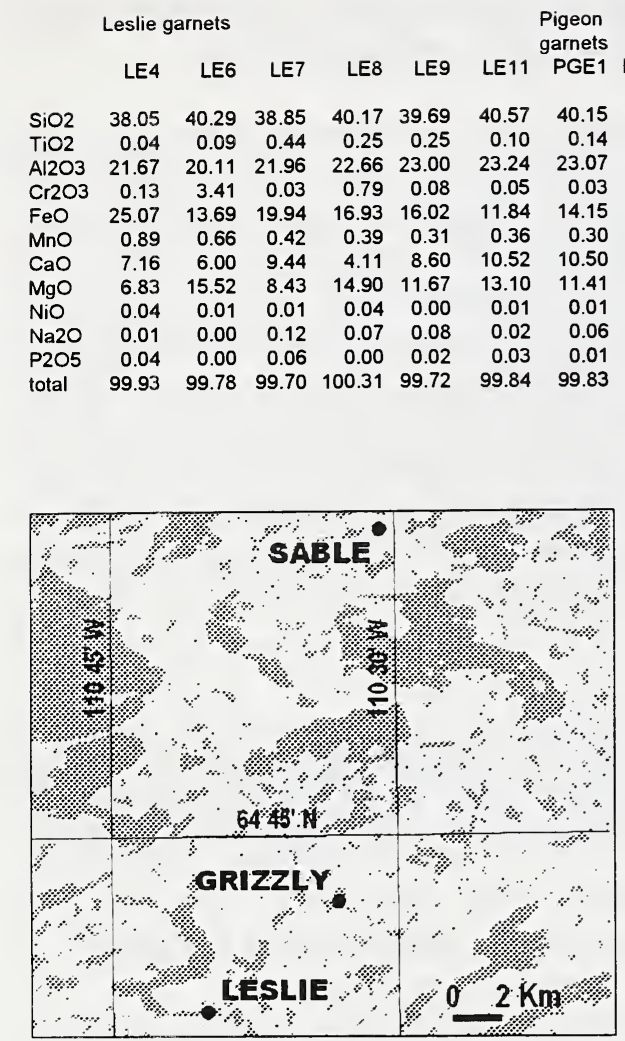

Fig. 1. Kimberlites in the study. Location of the Pigeon kimberlite is confidential.

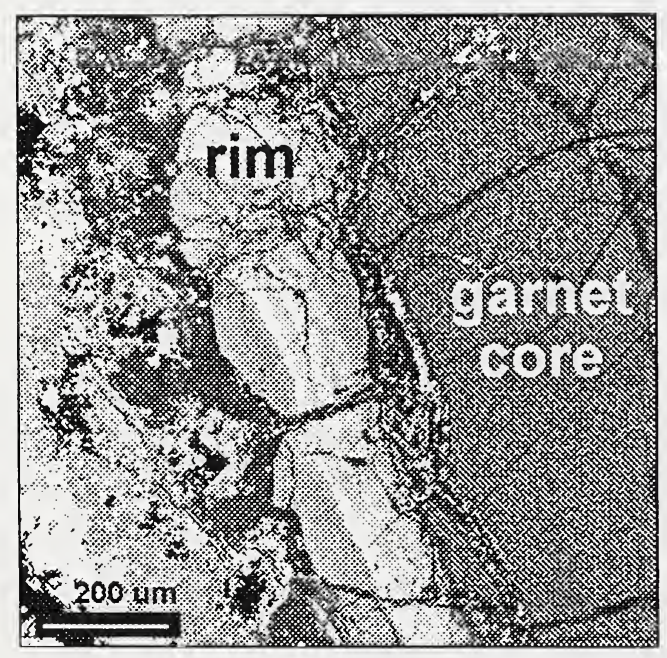

Fig. 3. Magnesium variations in a zoned garnet in Grizzly eclogite GE1 (secondary electron image).

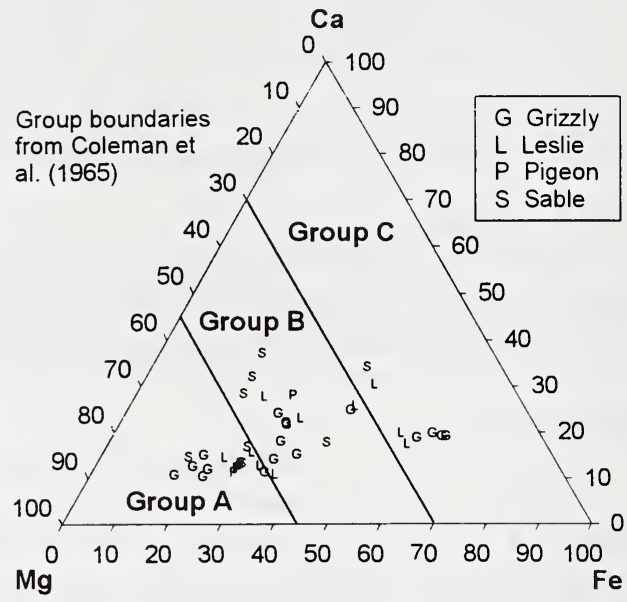

Fig. 2. Ternary diagram showing compositions of eclogitic garnets.

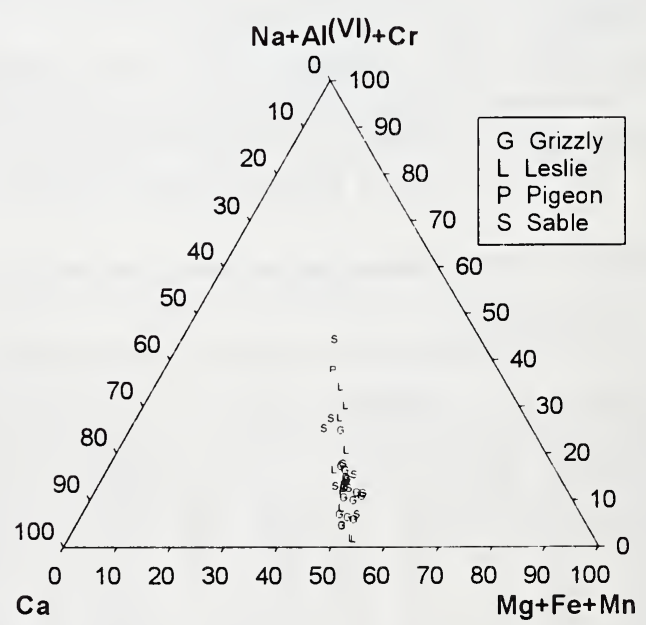

Fig. 4. Ternary diagram showing compositions of eclogitic clinopyroxenes. 